Journal of

Education and Practice (JEP)

Traditional Ewe Folktale: A behaviour modification strategy in the Early Grade Education classrooms in Ghana.

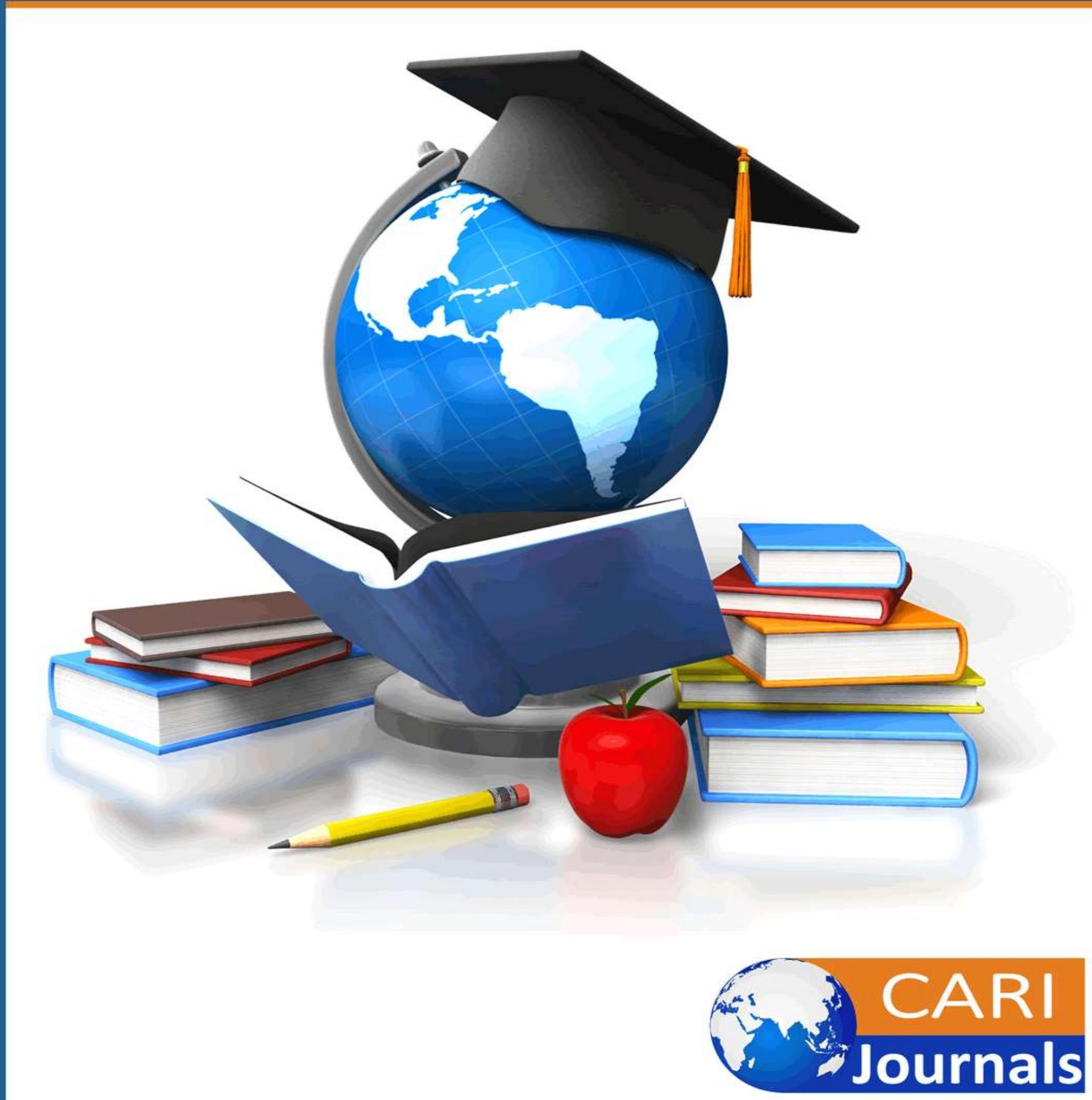


Journal of Education and Practice

ISSN 2520-467X (Online)

Vol.5, Issue No.4, pp $1-22,2021$

$\underline{\text { www.carijournals.org }}$

\title{
Traditional Ewe Folktale: A behaviour modification strategy in the Early Grade Education classrooms in Ghana.
}

\author{
${ }^{1}$ Innocent Yao Vinyo \\ Department of Languages, E.P College of Education, Amedzofe \\ ${ }^{2}$ Sampson Lucky Kudjo Yekple \\ Department of Languages, St Teresa's College of Education, Hohoe. \\ ${ }^{3}$ Daniel Atsu Adade \\ Department of Languages, St Francis College of Education, Hohoe.
}

\begin{abstract}
Purpose: Behaviour modification is considered a task of the home and the school. It is the duty of the school to nib in the bud any negative behaviour children pick from the home environment at the early grade level. This paper explores the impact and usefulness of messages from Traditional Ewe Folktales hereafter (TEF) in the training of early grade children in Ghana.

Methodology: This paper is a qualitative research. Primary data was collected from four separate storytelling sessions in home and school settings. Six stories were narrated in the home setting by two old ladies under moonlight for fifteen children each from a rural setting. In the school setting, one story each was narrated by two teachers in two different schools. Storytelling periods on the school time table was used. Three stories were considered for analysis; Two and one story each were randomly selected from the home and school settings respectively.

Results: It was found that educational values are imbedded in TEF. The educational values include the values of the society such as honesty, hard work, teamwork, patriotism and turn taking. Regular and purposeful use of these stories has the propensity of modifying behaviour. The paper concluded that when these educational values are tapped and developed through appropriate exemplars in the enactment of the school curriculum, behaviour modifications would occur with sustainability. The use of teaching strategies like role play, dramatization and songs can drive the behaviour modification. The paper recommended that TEF should be included in early grade classroom activities as a teaching strategy but not a means of whiling time. Parents should support teachers to gain more knowledge of TEF for classroom practices. The school base in-service training should be revived to equip teachers with knowledge of TEF and its application in the classroom.
\end{abstract}

Keywords: behaviour modification, early grade, Traditional Ewe Folktales, narration, storytelling 
Journal of Education and Practice

ISSN 2520-467X (Online)

Vol.5, Issue No.4, pp 1 - 22, 2021

$\underline{\text { www.carijournals.org }}$

\section{Background}

Traditional Ewe Folktales are considered and regarded as myths originating from an existing but obscure world. A narrator is seen as someone who is from the world of stories, gliwode governed by an old lady (Abadzivor, 2014). Characters of Traditional Ewe Folktales are normally trees, animals and spirits that are assigned the roles of human beings. Audience are always ready and prepared to listen to the mystries from the old lady of the mythical world (gliwode). Since it is an expression of wisdom full of lesson and new messages, narrators of Traditional Ewe Folktales are people with experience who are brave and considered wise. For obvious reasons, traditional leaders (chiefs and queenmothers), chief priests, Afa diviners and children are not permitted to narrate stories among Ewes. It is believed that traditional leaders are the custodians of indegenious knowledge and wit. Therefore if they become narrators of folktales, the source of their wisdom will be exposed and they will loose respect. As gate keepers, chief priests are the souls of Ewe communities and are seen as the facilitators of communication between the people and their gods. The voice of the gods are mythical, supreme and sacred. Hence if their massengers who are the chief priest are telling stories, it would be difficult for the people to differentiate between the messages from the gods and the messages from the stories. This may lead to defiance and disobedience of the instructions from the gods and the consequences would be infertility, mortality, drought leading to hunger and death. In order to prevent the anger of the gods, chief priests are not allowed to tell stories.

Afa is the oracle of divinition which reveals uncertainties surrouding an event and foretells the fate of people in relation to their future. Afadu (Afa code) is a message emanating from Afa divinition. Afa codes and Afa diviners are integral part of nearly every shrine in Eweland (Kumassah, 2016:161). It is believed that Afaduwo (Afa codes) are derived from the actions of animate and inanimate characters in unknown destination. Therefore if Afa diviners are telling stories, they would be complicent and expose the hidden secretes of the people thereby creating confusion of fear and panic. Children are inexperience and are expected to be trained as good listeners who would listen to the stories, learn from the substances of these stories to mould and modify their behaviour to become responsible and functionable natives of their communities. Based on this, they are not all consdered to narrate. They are to observe storytelling sessions to enable them become good orators in future. Any child who tries to narrate a story faces opposition from the people just because he/she is inexperience and the action is seen and considered as rebelious.

We have been reliably informed by the data that themes and messages from Traditional Ewe Folktales are capable of transforming human beings by moulding their behaviours into usable and responsible personalities. For instance, transforming lazy persons to a hard working ones, naive and timid persons to brave ones. Others are removing mistrust and greed from among the community members, ensuring successful mariages, ridiculing of wicked leaders and offering opportunity for people to actively participate in governance. In short, Traditional Ewe Folktales are purposefully used as a tool for education, social control and moral development. As the curriculum is seen as a selection from the culture of the society storytelling is captured as the $4^{\text {th }}$ 
Journal of Education and Practice

ISSN 2520-467X (Online)

Vol.5, Issue No.4, pp $1-22,2021$

$\underline{\text { www.carijournals.org }}$

sub-strand of the $1^{\text {st }}$ strand (oral language development) of the Ghanaian Languages and Culture curriculum in the current Pre-tertiary Education Curriculum (NaCCA, 2019).

\section{Introduction}

Public outcry nowadays about the increase in crime rate in Ghana is a matter of concern to many. Armed robbery, cybercrimes and ritual killings are becoming the order of the day. In recent times Cybercrime is said to have been mostly committed by the youth of Ghana (Ennin, 2015). As the society is analyzing strategies to minimize the issue of these crimes, Naame (2021) observes ritual killings in Ghana as a threat to national security. The school as an agent of change should be of great support in correcting such issues through behaviour modification strategies. The school requires logistics and professionals to churn out functional citizens for the society.

Early Childhood Education starts with the home and the community where the values and philosophies of the society are transferred unto the child through advice, counselling and corrections. Parents and responsible community members modify the behaviour of children by telling them interesting stories to enforce appreciable behaviour and to withdraw behaviour that is seen as a threat to the society. On the other hand, Ferinden (1970) argues that the teacher must assume the roles of behavioural engineer and through the application of behaviour modification techniques create a classroom atmosphere that not only leads to desired instructional outcomes but reduces the chances of the child learning inappropriate responses.

Behaviour is any attitude of an individual and other living organism that positively or negatively affect other members of a society (Skinner 1948). To some extent, behaviour is seen as a result of interplay between any organism and the environment from thoughts, actions, and emotions. To behaviourists' point of view, behaviour is seen as any activity of a person and any other living things. This explains that human behaviour is greatly influenced by hereditary and environment but can be corrected through knowledge acquisition.

Wanjohi (2010) emphasise that everything that goes on around the child which influences knowledge acquisition is the child's environment. Environmentalists such as Skinner (1938) and Bandura (1968) argued that the child's surroundings modify his/her behaviour since human behaviour, education and development are greatly influenced by one's interaction with the immediate environment. For instance, if a conducive environment is available at home and school, effective life-long learning takes place.

It is believed that social vices like armed robbery, cybercrime, ritual killing and corruption would be minimized if behaviour modification activities such as TEF are used in early grade practices. This lends its fact from the source that when learners are trained from the early age, they develop and harness the knowledge, skills and practices they acquire for self and societal development. Education is the main key that provides opportunity for people with knowledge, skills and courage to fight poverty for better future (UNICEP, 2012). Early Childhood Education has become a pivotal tool in development which should not be seen as a privilege but as a right to all people. According to the United Nation Human Right Declaration of 1948 Article 26 Clause 1, it is 
Journal of Education and Practice

ISSN 2520-467X (Online)

Vol.5, Issue No.4, pp $1-22,2021$

$\underline{\text { www.carijournals.org }}$

everyone's right to have access to education which shall be free and compulsory at the basic level. This shows that the Early Childhood Education which begins from birth to age eight must be free, accessible and compulsory for all children.

Unfortunately, Scharer (2017) argued that many prospective ECE teachers hold the preconception that indigenous knowledge (including storytelling and play) is something they can allow children to do during break time, something that children can do without the direction of the teacher something that gives teachers time to do other things. Scharer further explained that teachers are indirectly under the influence by parental opposition to the use of storytelling in the classroom as a teaching strategy; that it will affect their ability to complete the school curriculum. This position of the teacher would not encourage the use of storytelling as a teaching strategy and hence one would not consider the impartation of the educational values in storytelling to modify behaviour in the school. A conscious effort is needed to reorient teachers to appreciate the educational properties in storytelling as a useful strategy to modify behaviour in the school set up.

Stories are used as a medium by which a child is motivated to continue good behaviour and to discourage a behaviour that contradict societal norms. Dogbey (2016) suggests that every story or art statement is like an idiom, a portal through which one enters a world in order to explore, discover, gain experiences and interpret life so as to understand occurrences in a personally meaningful manner. Dogbey however lamented that glitoto (storytelling) with all its narrative qualities attracted low scholarly attention. This paper seeks to identify the values of Traditional Ewe Folklore and to explore how Pre-School Educators can use these values to modify children's behaviour. The study also explored some teaching strategies that can be used to impart the needed knowledge from the Traditional Ewe Folktales. The paper sets out to achieve the following research objectives;

1. To identify some of the educational values of Traditional Ewe Folktales.

2. Demonstrate how early grade educators can use these values to modify the behaviour of children.

\section{Theoretical Framework: Narrative Paradigm}

Fisher (1987), communication theorist, conceived that storytelling or reporting of events is an effective way of communication. His view is that people tell stories and observe narratives. The theory further says that stories are persuasive than arguments and the narrative paradigm helps us to explain how humans are able to understand complex information. The theory proposes that human beings are natural storytellers and a good story is more convincing than a good argument and narrative is the basis of communication. This suggests that human beings participate and play dual role during storytelling settings as a narrator as well as an audience. Participatory nature of storytelling makes it the most powerful and effective tool of modifying behaviour at early grade. Rogoff (2003) argues that people develop when they participate and interact with their cultural environment and participate in building on the past experience of the community. Meanwhile, the 
Journal of Education and Practice

ISSN 2520-467X (Online)

Vol.5, Issue No.4, pp $1-22,2021$

$\underline{\text { www.carijournals.org }}$

conducive learning environment enables early grade learners to actively participate in storytelling activities. (Yekple, Vinyo \& Kumah, 2021) in support of Rogoff mentioned that classrooms are expected to be the expression of reality and early grade learners are to be provided with the relevant support to exchange ideas in every learning situation. An indication that stories are as old as human being and human life is built on stories from which they learn. However, the proponent of the process or the reinforcement theory Skinner (1938), proposes that a behaviour can be modified through reinforcement, punishment and extinction. According to Skinner, appreciable behaviour can be reinforced by rewards. Punishment is applied in opposition or to stop those behaviours not needed and require extinction to put to an end a learned behaviour that is detrimental to the society. The theory identifies positive and negative reinforcement as a means of reforming and transforming undesirable behaviour. Positive reinforcement motivates a behaviour to be repeated while negative reinforcement withholds undesirable behaviour.

\section{Literature Review}

Finnegan (1970) identifies entertainment, imagination, education, practise in public speaking, recording, humour, elegance, ridicule, obscenity and moralizing as the most significant functions of folktale. This acession justifies why folktale is very crucial in the lives of individuals. However the reason for telling a particular story is determined by the narrator (Agyekum, 2013). Storytelling is one of the traditional methods which is used in contemporary world as a means of guiding us in our life journey. It also helps school children to develop sound psychological and physical wellbeing that individuals need to be useful in society where he/she settles (Ali, 2016). As a stock of knowledge, folktales provide school children with variety of life experiences by listening and observing how the narrator uses characters in the story to deliver the intended message. In choosing the reason, the storyteller considers the language, the characters, the setting, the plot, the theme and the age of the audience. A skillful storyteller enables you to identify with one or more characters and to become concerned about their situations, intrigued by their actions and perhaps instructed by the resolution of their conflicts (Gorden \& Kuehner, 1999). Meanwhile Shabib, Naderi \& Makvandi (2015) observed that children associate themselves with good characters according to their understanding. This understanding changes and modifies their behaviours. With the help of a good story with good characterization and appropriate theme related to the child's challenges and developmental background, a change in behaviour occurs. During storytelling, participants' attention is arrested by the narrator whose purpose is to win the interest of the audience. Children's attention is normally drawn to the action of the characters who they either admire or hate. Traditional Ewe Folktales is one of the oldest ways of addressing issues of life among the Ewe people since it is full of interesting characters, themes and messages which create sense of suspense. Audience spend their precious time with narrators anytime stories are being told. Because of this Rose, (2017) is not far from the truth when she attests to the fact that storytelling among the Ewes of the Volta Region of Ghana started with their ancestors and they use it to teach and impart into the youth their community values. 
Journal of Education and Practice

ISSN 2520-467X (Online)

Vol.5, Issue No.4, pp 1 - 22, 2021

www.carijournals.org

Storytelling offers the child with the opportunity to meditate on the same experience that they could think about or put into use in future (Erickson, 2018). However, storytelling in pre-school enables learners to interact with the learning environment and pick the desirable behaviour from characters as they grow and advance in knowledge. Ireland (2021) also observed that rewarding politeness and good manners teaches children that using good manners and polite words give a better reaction than throwing a tantrum. Social story of positive reinforcement is the reading of a story that is specifically made to help the child to handle specific social situation encountered with given positive reinforcement aimed to increase the targetted behaviour (Apprianti, Sahrani \& Basaria, 2017). Meanwhile the narrator's skills in expressing the theme, setting, plot and characterization of Traditional Ewe Folktales motivates the child to drop undesirable behaviours. The child, in effect desires to develop interest in messages of the story that enhance societal acceptable behaviour. For instance the exploits of the heroe in a traditional Ewe folktale serve as a role model for children. It is therefore pertinent to note that folktale which is one of the elements of oral tradition among others such as myth, legend, fables, etc is basically meant to keep the past alive; introduce young people to history, beliefs, and religions of their society. It teaches moral lessons such as hospitality, honesty, kindness, courage, empathy, forgiveness, hard work, communalism etc, and to warn against negative qualities; greed, wickedness, foolishness, mischief etc. (Joshua \& Wanjohi, 2010). Having realised the values and morals in indigenous knowledge and the significant role it plays in behaviour modification, Amlor (2016) states that the rate at which foreign culture is poluting our values as a people is a wake up call for the Ewe society to resort to the use of traditional indegenious knowledge as a means of educating children to enable them acquire traditional knowledge to become responsible adults. In this regard, the school curriculum must incorporate indigenous knowledge. To support this, Hama (2003) maintains that the curriculum of the school regardless of its pattern of organization is a selection from the culture of what must be handed over to the new generation.

The early grade is a transition from home to school, a time the teacher must be warm, friendly, fair, offers praise, encouragement and withhold any form of punishment and treatening behaviours (T-TEL, 2016). Using Traditional Ewe Folktales as a creative pedagogy at early grade education is suitable for behaviour modification since it can be used to treat negative behaviour and to appreciate positive behaviour in children. While you might focuse on stopping negative behaviour, it may be just as important to praise and reward positive behaviour as well (Ireland, 2021). However Skinner (1948) bemourns punishment as a way of correcting deviant behaviour and recommends that pleasant experiences (reward) are positive reinforcers because they make desired connections between stimuli and response. He indicates that unpleasant experiences are negative reinforcers because they make learners to avoid undesirable responses. The rise and fall of a hero in a TEF exposes the child to alternative behaviour from which he/she chooses the appreciable ones. Storytelling is one way in which people better understand the events that have happened in their lives (Lawrence \& Paige, 2016). The literature on story telling though in an appreciable volume, was not focusing on TEF and behaviour modification suggesting a need for a study of this kind. 
Journal of Education and Practice

ISSN 2520-467X (Online)

Vol.5, Issue No.4, pp 1 - 22, 2021

$\underline{\text { www.carijournals.org }}$

V Methodology

This is a qualitative type of research which adopts ethnography as its design. Observation and interview was used to collect the data. The study took place in the Akatsi South District of the Volta Region of Ghana. The unit of analysis was six stories narrated by two old ladies and two teachers. These narrators were conveniently selected based on an earlier discussion with elderly women in the community including the teachers. Three stories were purposively selected for the analysis. The stories have been in both rural home setting and two lower primary classroom settings. The reserachers sat in the story sessions and observed the proceedings. The participants in all the sessions sat in a horse shoe form. In consideration of the attention span of the children who are below ten years, the teachers were able to tell one short story which was full of activities such as singing, clapping and dancing. These storytelling sessions were done in the Ewe Language which is the main Language of the people as well as medium of instruction at the earlygrade level. The stories were recorded and transcribed. The two storytelling settings were selected to measure how the informal education and formal education practices can collaborate in the behaviour modification agenda. This would also display how effectively the home and school can collaborate to educate the early grade learners for life long activities which would enable them to put up acceptable behaviour in the global society. A simple random sampling test was done. The title of the six stories were written on pieces of paper each representing a story, folded and thrown into a bowl. Two of these papers were randomly chosen from the bowl and their respective stories were used for this study. The same process was repeated for the classroom stories and one was selected. The data was collected observing strict COVID 19 protocols.

\section{Findings}

VI.i Story one: Why dog hates partridge

The characters in this story are the hunter, Monkey, Dog, Dog's wife, Partridge and her children.

Monkey and Dog were very good friends. They did things in common as friends. One day, they decided to put their friendship to test by playing a game of identity. Monkey told his friend that he would not be able to recognize him when he dressed. Dog laughed and wondered how special could Monkey dress to cover his identity and said 'no matter how Monkey dressed, he, Dog would surely make him out.' One morning, Dog received a visitor he did not recognize. After the wife served the visitor, he complained to the wife about the visitor he could not identify. He decided to take the visitor to the next village to see if anyone could identify him. Nobody was able to identify Monkey in the village. When Monkey went home, he told the wife that he visited his friend but Dog could not recognize him. Two weeks later, the two friends met and Monkey wanted to know when they would begin the recognition game they have decided to play? Dog never knew that Monkey had already started the game and he was the one who disguised himself and visited him two weeks ago. Because of this, Dog said he would be the first to set the ball rolling by starting the game. 
Journal of Education and Practice

ISSN 2520-467X (Online)

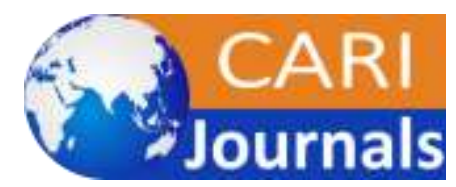

Vol.5, Issue No.4, pp $1-22,2021$

$\underline{\text { www.carijournals.org }}$

It was a noon day when Monkey was resting after the day's work. 'Agoo,' a visitor entered Monkey's house. Beautifully dressed with hat on his head and sword in his hand. It was very difficult for Monkey to identify Dog. Monkey said to himself, 'it seems I have seen this stranger before but I cannot recognize him and the only thing I can do is to sing and see if the stranger can introduce himself.' Monkey started singing a song;

"Amedzro ade dze afenye

Nyemenya ejko o

Kuku le ta ne

Nyemenya ejkı o

Adekpui le asi ne

Nyemenya enkı o".
"A visitor I had

I don't know him

A hat on head

I don't know him

A sword in hand

I don't know him".

Dog didn't introduce himself to Monkey after singing the song. Monkey took Dog to the neighbouring villages but nobody recognized Dog. They continued the journey to see if anyone could identify Dog until they met Partridge and her children dehusking beans in the farm. When they met her, Monkey told Partridge that he had a visitor who he didn't recognize that is the reason for their journey. 'Ha ha ha,' Partridge laughed and fell down gblooo, and asked Monkey, 'are you saying that you could not identify this person?' Monkey replied and said 'I cannot identify him at all.' Partridge invited her children to come and see if they could identify the stranger. The children burst into laughter, they laughed, laughed, laughed and fled away. Partridge asked again, 'Eiii Monkey, are you saying that you don't recognize Dog?' Immediately, Dog ran after Partridge, wanted to catch her for exposing his identity. 'Prrr.' Partridge flew and landed on a tree. Dog was under the tree looking at Partridge at the top of the tree. Having seen Dog looking into the tree, a hunter who was hunting for game also decided to look into the tree. He saw Partridge in the tree. 'P-o-o-o' the hunter shot at Partridge, she fell, Dog pounced on her and killed her. From that day Dog hates Partridge.

\section{VI.ii Story two: The hunter and the Bull}

Characters in this story are the Hunter, Bull, an old lady and the hunter's son.

Once upon a time, there lived a hunter who married two wives. One of the wives passed on leaving behind a boy. The boy lived with the father (the hunter) together with an old lady in a cottage. One day, the hunter brought home a female buffalo (Cow) as a game from his hunting expedition. The hunter had a sacred shrine where he kept animal jaws (adekpo). The jaw of the cow was also kept in the sacred place. Whenever the hunter goes to hunting expedition, he instructs the son to dry the new animals' jaws.

As usual, the hunter leaves the boy for a hunting expedition. That faithful afternoon, something happened unexpectedly. 'Tadza, tadza, tadza,' a very big Bull came to the hunter's cottage where the boy was drying the animals' jaws. The boy having seen this wanted to run but the Bull asked him to come back. When the boy came back, the animal asked the boy about the whereabouts of 
Journal of Education and Practice

ISSN 2520-467X (Online)

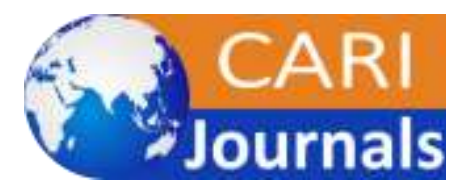

Vol.5, Issue No.4, pp $1-22,2021$

www.carijournals.org

the father and the mother. The boy answered that the father went to the farm and the mother was not around. The Bull asked the boy if the father has evedada (evedada is a play game that is normally played between two contestants: two people or two groups of people). The boy answered and said, "Eee (yes) my father has evadada" and the animal asked him to bring it for them to play. Few minutes into the game,

Đevi, devi va míxlẽ lãglã (come let's count animals' jaws), the Bull instructed

Đevi, devi va míxlẽ lãglã (come let's count animals' jaws), the Bull repeated

This sent fear into the spine of the boy. The boy was walking slowly because he was afraid and reluctant to go but the Bull pushed him to go and bring the animals' jaws for them to count. Realizing that the boy was not willing to go, the Bull went and brought the animals' jaws himself. The Bull picked one animal's jaw and asked the boy 'Đevi, lã ka fe glãe nye sia?' (which animal's jaw is this?) The boy sang a song;

$\begin{array}{ll}\text { Ade maletsi } & \text { Hunter's game } \\ \text { Ade maletsi } & \text { Hunter's game } \\ \text { Ezi wo glãe } & \text { A deer's jaw } \\ \text { Ade maletsi } & \text { Hunter's game } \\ \text { Adela bebefue wui } & \text { Brave hunter's game } \\ \text { Ade maletsi } & \text { Hunter's game } \\ \text { Ezi wo glãe } & \text { A deer' jaw } \\ \text { Ade maletsi' } & \text { Hunter's game }\end{array}$

The Bull picked another animal's jaw and asked Đevi, lã ka fe glãe nye sia? (which animal's jaw is this?)

The boy answered again through singing;

'Ade maletsi

Ade maletsi

Dzata wo glãe

Ade maletsi

Adela bebefue wui

Ade maletsi

Dzata wo glãe

Ade maletsi'
'Hunter's game

Hunter's game

A lion's jaw

Hunter's game

Brave hunter's game

Hunter's game

A lion' jaw

Hunter's game

The Bull saw the jaw of his wife (Cow) but did not touch it. They continued with the counting of other animals' jaws. At long last, the Bull picked the jaw of his wife and asked, 'Đevi, lã ka fe glãe nye sia? (which animal's jaw is this?). The boy sang the song;

Ade maletsi

Ade maletsi

Eto wo glãe
Hunter's game

Hunter's game

A Cow's jaw 
Journal of Education and Practice

ISSN 2520-467X (Online)

Vol.5, Issue No.4, pp 1 - 22, 2021

$\underline{\text { www.carijournals.org }}$

Ade maletsi

Adela bebefue wui

Ade maletsi

Eto wo glãe

Ade maletsi'
Hunter's game

Brave hunter's game

Hunter's game

A Cow's jaw

Hunter's game

Stirring at the boy, the Bull told him to tell the father that he would be back tomorrow so he should be around for them to play the (evedada) game. 'Tadza, tadza, tadza,' the Bull left.

The boy told the father about the Bull's visit but his father doubted it and told the boy in the face that he was telling lie because Bull had not stepped into that cottage before. The following day, the hunter left the boy in the house and went to farm. 'Tadza, tadza, tadza,' the Bull came to the house. He asked the boy where was the father and the boy said the father had gone to the farm. The Bull asked the boy to continue the counting of the animal jaws after few minutes of playing of the play game (evedada). They counted a quantity of the animal jaws after which the Bull told the boy to tell his father that he (Bull) was in the house and would be back the following day. 'Tadza, tadza, tadza,' the Bull left. There was an old lady in the house who witnessed the visits of the Bull and what went on during the visits.

When the hunter came back, the old lady briefed him that whenever he left the house a huge Bull had been coming to the house. She told him that when he came, he played evedada game with the boy for some time. He later took him to the sacred shrine where the animal jaws are kept and engaged him in counting of the animal jaws from the sacred shrine. The old lady told the hunter that when they were counting the jaws, the Bull used to scratch the earth closer to where the boy was sitting with his hoofs, jumped backwards ran towards the boy and hit where he scratched and the sacred shrine with his horns. The old lady told the hunter that the Bull's actions were very scaring making her speechless and afraid anytime the animal was around. The hunter after hearing this, looked at the old lady and said that she is also a lair because he (the hunter) had not seen any animal in that cottage since his childhood.

One day when the hunter was going to farm, the old lady reminded him that the Bull would be coming to the house that afternoon so he should come and hide in her room. The hunter refused but told the old lady that he would rather hide behind his hut. Immediately, tadza, tadza, tadza the Bull had arrived. That day, the boy was happy because his father was around to see what he had told him about the Bull's visitations. When they started counting the animals' jaws, the boy was looking at where the father was hiding but he could not see any sign because the father was sleeping. This continued for sometimes until a hawk from unknown place hit the face of the hunter 'praaa.' He suddenly woke up and saw the Bull with the son counting animals' jaws from the sacred shrine. Having seen this, he told himself that he had seen it with his eyes that his son is not a liar. He shot the Bull from his hiding and the boy was very happy. 
Journal of Education and Practice

ISSN 2520-467X (Online)

Vol.5, Issue No.4, pp $1-22,2021$

www.carijournals.org

VI.iii Story three: The greedy friend

This story was narrated by the KG2 teacher to her pupil during one of their story telling periods.

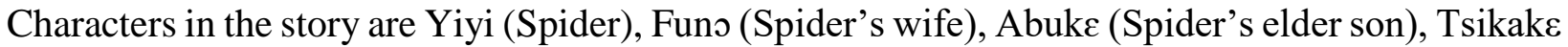
(Spider's daughter), Agbakake (Spider's son), Đetsyəevi (Spider's friend) and Èté (corn milling stone).

Once upon a time, Yiyi and his family lived in a village. There was a hunger due to drought. Food was so scarce that people started dying in the village. Yiyi and Đetsəevi were very good friends. One day, Yiyi's children visited Đetsyoevi's children and realized that they were eating ewokple (staple food of the Ewes prepared from corn flour). When they came home they told their father (Yiyi) that when they visited Đetsyoevi's children they saw his children eating ewokple. Yiyi wanted to know if it is true that Đetsyoevi and his children were eating ewokple. His children said it is true since they saw it with their naked eyes. Yiyi quickly ran to Đetsyəevi to see for himself if it is true that, he and his children have been eating ewokple. Đetsyoevi agreed and told Yiyi that there is Ète (corn milling stone) in a certain forest producing corn flour. Yiyi demanded from his friend if it will be possible to take him to the forest for him also to collect some of the flour for food. Đetsyəevi answered and said, "it is possible my friend, what are friends for?" The following day, Đetsyoevi took Yiyi to the forest and they collected a lot of corn flour. Having seen this, Yiyi decided to be going to the forest secretly without informing his friend. Yiyi will go early in the morning alone and collect all the corn flour leaving none for his friend. One day Yiyi told his wife that he will bring the Èté home to make it easy for them to be collecting corn flour anytime they needed it. He went to the forest struggling to carry the milling stone when his friend came to collect corn flour. His friend asked him where he was carrying the stone to and he said he was taking it to his house. His friend collected the corn flour and left. When Yiyi realized that he could not carry the stone because it was very heavy, he brought his elder son Abuke to help him carry the stone onto his head. They tried and put the stone onto the head of Yiyi but he could not walk because of the weight of the stone. It took Abuke a lot of time and strength to remove his father from under the stone. From that day, Yiyi became flat.

\section{Discussions of the findings}

This part of the study discusses the findings. The educational values of the stories are thematically analyzed and discussed respectively. Suggested strategies the early grade teacher can adopt to impart these values are captured in this section

Traditional Ewe Folktales are clear and explanatory as far as education is concerned. The narrator has a purpose of telling a particular story. In other words, stories are directed at a suspected behaviour, either to enforce it or to shape it. Ewe folktales target various dimensions of appreciable behaviours that would enable their young ones to fit into societies in which they found themselves. Since Ewes believe that punishing people is a sole duty of the gods, they don't use punishment as 
Journal of Education and Practice

ISSN 2520-467X (Online)

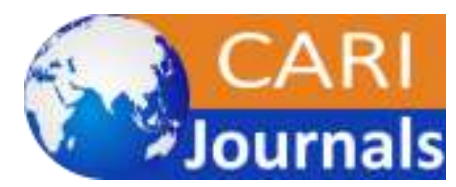

Vol.5, Issue No.4, pp 1 - 22, 2021

$\underline{\text { www.carijournals.org }}$

a means of correcting people but resort to storytelling as a measure to modify the behaviour of children. (Fisher, 1987)

\section{VII.i Friendship and its implications}

Most people are wayward because of the type of friends they kept when they were young. Some even lost their lives just because they kept bad friends. Jobs collapsed due to bad and unfaithful friendships. As the saying goes, birds of the same feather flock in union, innocent people are even incarcerated to atone for the criminal acts of their friends. The story of friendship between Dog and Monkey is one of the Traditional Ewe Folktales that cautions the youth to be careful of the type of friends they keep since their friends help in shaping their lives. As portrayed in the story, Dog and Monkey are good friends who planned to do something together but Monkey secretly did it without Dog's concern. Monkey did not tell Dog what he did even when Dog reminded him of what they planned to do. It is an open secret that most of the criminal acts perpetrated nowadays are due to bad friendship and peer influence. This story will enable the youth to scrutinize the type of friends to keep so that they would not fall victims to unfaithful friends. However in story three, the value of friendship for support in times of problems was highlighted. The greatest thing we expect in life is to have good friends who will be with us in difficult times. Life is full of difficulties and needs. Sometimes a little support from a friend may be a solution to a problem. Good friends are those who see their friend's problems as theirs. In the global society, developed countries support developing and struggling states with aid in terms of finance, technology, health etc. A current example is the support in accommodating Covid 19. They sacrifice for their friends to come out of their problems. A good friend gives a good result. This is what the story wants us to learn and believe. Yiyi's friendship with Đetsyoevi yielded a good result by supporting the life of Yiyi and his family. Yiyi and his family survived the hunger because Đetsyoevi is a good friend. Đetsyoevi demonstrated that he is a good friend when he asked Yiyi, "What are friends for?" Just imagine what would have happened to Yiyi and his family if his friend, Đetsyoevi is not a good friend. This story will enable the children to learn how to support each other and have fellowfeeling for friends.

\section{VII.ii Acquisition of skills and knowledge}

'My children are known by the work I do, I'm a fisherman, my son is a fisherman, and my daughter sells fish because her mother is a fishmonger.' Ewes believe in training their young ones with employable skills to prepare them for the tasks ahead. That, they would not grow and be desperately searching for nonexistence jobs. That is parents train their children informally to enable them acquire employable skills to gainfully employ themselves as they grew. It is not coincident that Monkey and Dog met Partridge and her children in farm as illustrated in story one (1). According to the story, Partridge and her children were seriously working in farm when Dog and Monkey met them. This is to indicate that farming is the main occupation of the Ewes and as a farmer, Partridge provides the children with the opportunity to acquire the skills of farming which will enable them to be employed and satisfied. Lack of job is the main cause of criminal activities 
Journal of Education and Practice

ISSN 2520-467X (Online)

Vol.5, Issue No.4, pp 1 - 22, 2021

$\underline{\text { www.carijournals.org }}$

bedeviling our societies nowadays. Since the devil finds work for the idle hands, some of the jobless youth resort to inhuman activities to support themselves. The three stories touched on how parents see their children and how children respond to their parent's demands. The story demonstrate how children respect and treat their parents. The children of Patridge follow their mother to the farm. Despite the strange visitation of the Bull, the hunter's son did not disobey the father. Despite the size and weight of the milling stone, Yiyi's son, Abuke did not refuse to help the father to carry it home. The stories portray how Ewes train their children not to live a rebellious life but to respect and obey their parents and others. This will enable children to learn to be respectful for they know the consequences of rebellious, disobedience and disrespectful life.

\section{VII.iii Children don't interfere into adult's affairs such as politics}

Ewes frown children's interference into issues being discussed by elderly people especially politics. When this happened, in the case of Kofitsey for instance in Togbe Kpeglo II, he rebuked his daughter Ama not to interfere into issues that do not concern her (Bidi-Setsoafia, 1989). It is an abominable behaviour for a child to meddle into matters being discussed by elders. This is due to the belief by the Ewes that children are not mature enough to make any meaningful contributions when elders are discussing issues. Also, they think that children do not develop the skills in language use that would enable them flow with elders when they are talking. Ewes therefore, train their young ones to be good listeners. It is also done to protect the children from becoming victims of the furry and anger of any elder that may be offended whenever children meddle into any matter elders are discussing. This is displayed in the story when Partridge invited her children to come and identify Dog. It is obvious in the story that Dog did not hate Partridge's children simply because they did not say anything. Đetsoevi ask Yiyi where he was sending the stone when he met him and his son the forest but the son did not interfere as portrayed by the third story. Also, the second story tells us that the old lady told the hunter about the visits of the Bull. Although the scene is scaring and the son's life is at stake, the boy did not meddle into their discussions. This will be a signal to the children that it is not good to become part of elders' discussions, if you are not invited.

\section{VII.iv The value of truth and honesty}

The truth is expensive but set people free emotionally, mentally, morally, academically and physically. Therefore, it is good to tell the truth as it is. The story did not let us to appreciate falsehood instead of the truth since all the characters that Monkey met did not say what Dog is not. Apart from Partridge, others only said they did not know who the stranger was. It is not easy for people to tell the truth because the truth hurts. People die for saying the truth. People become enemies just because they told the truth. The truth is one's ability to expose something to clear the doubt in the mind of others. The reality is what happened to Partridge when she told the truth about the identity of Mr. Dog. The message is that people should prepare for the consequences as they tell the truth and to tell nothing but the truth as seen exemplified in story one. In the story, Dog hates Partridge for telling the truth. We should prepare for the consequences of telling the truth. 
Journal of Education and Practice

ISSN 2520-467X (Online)

Vol.5, Issue No.4, pp $1-22,2021$

$\underline{\text { www.carijournals.org }}$

Telling enjoins the society to develop trust for individuals who embraces it. In story two, the hunter said, 'Now I know, my son is telling the truth.' Although story one portrays that consequences of telling the truth is hatred and death as it happens to Partridge, the story did not say that it is Dog who had kill the Partridge. The hunter did not kill the Partridge for telling the truth. The second story demonstrates the benefits of being truthful. If the boy had lied to the father, the Bull would have killed him.

\section{VII.v Greed is evil}

Greed, which is the main theme of the third story is a good lesson for us because of high level of corruption and criminality being perpetrated against innocent citizens in our societies nowadays. In this story, Yiyi deform when he tried to possess something that does not belong to him. Greediness is one of the behaviours Ewes frown since they see a greedy person as a thief, a robber or a murderer because such a person is never contented with what he has. Dukeklẽgbogbo (the spirit of greed) in Ewe Language means spirit of greed. To them, greed is a spirit which possesses people to own anything they want by hook or crook. A greedy person does not care how he accesses what he needs. For instance, a greedy person uses any means to acquire wealth even if it costs the life of his mother. What he needs is wealth. For this reason, Ewes do everything possible to discourage children from being greedy. They employ any available correctional measure to nib in the bud any traces of greed in their children's behaviour as they grow. Having realized that the corn milling stone (Èté) is capable of giving them food, Yiyi does not care if he could carry it, he does not care who it belongs to and he does not even care about his friend who showed him the place. All he wants is the corn milling stone. As a result, he became disabled by losing his natural form. What this story teaches is to be content with the little one has and not annex anything that belongs to someone or the society. That, chasing anything that belong to somebody can lead to death or deformity as in the case of Yiyi. That, children should be satisfied with what they have and not to take anything that does not belong to them.

\section{VII.vi Cheating denies the society of opportunities}

It is clear from story three that we should not cheat on our friends by doing badly for good but should live symbiotically by supporting each other. A popular Ewe adage says 'the left hand washes the right hand and the right hand washes the left hand', stressing the fact that life is incomplete until we support each other. For it would not be enough if the right hand refuses to wash the left hand. This lesson from the story is to foster good relationship between friends and among people for healthy and cordial relationship. According to the story, Yiyi goes to the forest early in the morning and collects all the corn flour leaving none for his friend who showed him the place. Whenever his friend goes later, he finds nothing to collect. The behaviour of Yiyi did not only deny his friend and the family of food but also shows an act of ungratefulness. Children should live cordially with their friends to foster good relationship by supporting each other. 
Journal of Education and Practice

ISSN 2520-467X (Online)

Vol.5, Issue No.4, pp 1 - 22, 2021

$\underline{\text { www.carijournals.org }}$

\section{Classroom strategies and expectations}

VIII.i The Role of Early Grade Educators in Behaviour Modification at Early Grade Level: Goal 1 of Education for All (EfA) advocates for expanding and improving comprehensive Early Childhood Care and Education, especially for the most vulnerable and disadvantaged children (UNICEF, 2012). Research has shown that the systematic application of behaviour modification principles can bring about needed behaviour reformation in educational settings. The teacher must assume the role of behavioural engineer. Through the application of behaviour modification techniques, the teacher creates a classroom atmosphere that does not only lead to desired instructional outcomes but reduce the chances of a child learning inappropriate responses (Apprianti, Sahrani \& Basaria, 2017). Hyperactive, aggressive, negativistic, dependent, and withdrawn children are discussed as well as specialized techniques for handling these children. Vicarious reinforcement such as storytelling can be used to reward good behaviour. The teacher might focus on stopping negative behavior. It may be just important to praise and reward positive behaviour by appreciating good and appreciable behaviour. It can be any polite or good manners put up by the hero or other supporting characters in the story. This teaches your little ones that using good manners and polite words gives a better reaction than throwing a tantrum (Ireland, 2021). The position adopted by behaviour therapists is that all behaviour is learned and consequently, if all behaviour is learned then all behaviour can be unlearned" (Williams, 1975). The action and inaction of an early grade educator can result to the dropping of a learned behaviour. Children may acquire deviant and wayward behaviour from the environment due to peer influence and or societal moderation. These behaviours are expected to be trimmed during the early grades education to prepare them adequately for life. It is the expectation of this paper that if ECE teachers are trianed in the knowledge, skills and pedagogical strategies of using indegenous knowledge of storytelling in the classroom, behaviour modification may be better effected.

VIII.ii Identification of the problem behaviour: Many children show signs of negative behaviours such as lying, defiance, petty stealing, disrespectful behaviour, impulse behaviour, aggressiveness, greed and temper tantrums. Children put up these behaviours to either satisfy their desire, gain attention or to feel better about themselves. If these behaviours grow with the children, they may be wayward and become nuisance in the society. Some of the criminal behaviours have been acquired from peers and other socialization agents which had not been identified and controlled. For instance, if a child used to steal pencils in class and it has not been identified and addressed, it is possible that the child may grow and become a thief or a robber. Some of these negative behaviours are also practiced in the home at the blind sight of the parent. One can observe that the complex repertoire of behaviour displayed by members of society are to a large extent acquired with little or no direct tuition through observation of response patterns exemplified by various socialization agents (Banduras, 1969). It is the responsibility of parents and care givers to identify such problems and support the early grade teachers to enable them adopt the needed strategies to curb them. Unfortunately, most parents of the $21^{\text {st }}$ century leave their children under the watch of inexperienced caregivers who could not identify these behaviours early enough for any meaningful and timey interventions. In the school, some of these cases are identified and 
Journal of Education and Practice

ISSN 2520-467X (Online)

Vol.5, Issue No.4, pp $1-22,2021$

www.carijournals.org

reported to the teacher by the children themselves. For example if a child exhibits the tendencies of greed by forcefuly annexing the items of his colleagues, this child will be reported to the teacher by his friends. The teacher will identify the problem of the child by the help of his colleagues. If the problem behaviour is identified, it will be easy for the teacher to develop strategies from the Traditional Ewe Folktales, narrate it to them to address the unfortunate behaviour. The above is in line with Yekple, Vinyo and Kumah (2021) suggesting the inclusion of traditional knowledge training courses in the curricular of colleges of education to equip the pre-service teacher for the classroom. Skills from the traditional knowledge will in a long way help the early grade teacher to identify children's negative behaviour for modification.

VIII.iii Pedagogical strategies: Teaching strategy is a generalized plan for a lesson which includes structure, instructional objectives and an outline of planned tactics, necessary to implement the strategies. Furthermore, teaching tactics are that behaviour of the teacher which he manifests in the class i.e., the developments of the teaching strategies, giving proper stimulus for timely responses, drilling the learnt responses, increasing the responses by extra activities and so on (Isaac, 2010). The measures adopted therefore by the early grade teacher must target and deal with a suspected negative behaviour. There are many traits of indegenous knowledge imbedded in Traditional Ewe Folktales for moral control and behaviour modification. The setting, the characters, the plot and the theme are greatly influenced by the culture and the tradition of the people. It will be prudent if the early grade teacher develops the teaching strategies within the scope of curricular needs of the children taking into consideration their sociocultural environment and their experience. This in a long run do away with boredom creating suspense by arresting the interest of the children since the strategies are locally oriented. The strategies must be specific enough to attack any intended negative behaviour that needs modification.

Children's attention is normally caught by what they see. Interesting pictures of some of the influential characters from a story will be very useful in the teaching and learning process. Scenes that are educative can be captured in a form of pictures to enable children to identify the substantive events that please them and valuable for transforming their behaviours. That is if the early grade teacher identifies a negative behaviour she wants to modify. She can use a picture of a scene from the story that ridicules such behaviour. The picture can be used as a starter (pre lesson activity) before the story is narrated or after the story had been narrated as a focus of the previous lesson during another story telling time. What is necessary is the ability of the teacher to effectively communicate the lessons in the scene to terminate the problem behaviuor of the child. From the third story for instance, Yiyi (spider) out of greed, decided to carry the milling stone (èté) to the house without the concent of his friend who introduced him to the forest. A picture portraying the concequences of Yiyi's action can be used by the teacher to discouradge a greedy behaviour of a child.

Involvement of children in a lesson delivery is crucial in behaviour modification process. One of the best and trusted pedagogical strategies a teacher carries his pupils along by participation. The teacher does this by creating a space for them to get involved. In view of this, an early grade teacher who is determined to modify a child's behaviour may assign roles to the children to play. Since 
Journal of Education and Practice

ISSN 2520-467X (Online)

Vol.5, Issue No.4, pp $1-22,2021$

www.carijournals.org

children like playing, support from their teachers would ensure mastery of the knowledge and skills of learning through play (Yekple, Vinyo \& Kumah, 2021). A short but interesting plays from the story can be dramatized by the children as part of the teaching strategies to deal with a questionable behaviour. A child may be assigned a role of a character from the story targeting the behaviour the teacher identified and plan to modify. A good and interesting play from a Traditional Ewe folktale may arouse the children's interest. On the other hand, a child may appreciate the bravery and the charisma of a character to the extent of being known and identified as his role model. For instance in the second story, a child may admire the bravery of the Bull who seeks to revenge for the wife. If a child plays the role of the Bull in the play, his admiration of the bravery of the Bull may earn him the name Bull and may grow and become a brave person.

Ryhmes and songs can be used from an Ewe folktale narrated by a teacher to early grade pupils during story telling period. The rhyme can be coined from the context of the story or from a song within the story. A rhyme from the content of the story may focus on an identified behaviour which the teacher wants to mould. On the other hand, a rhyme from a song in the story may not necessarily target the problem behaviour of the child yet anytime it is being recited, the children may recollect the events in the story and remember the consequences of a character's action. Example of a song from the first story is,

A visitor I had

I don't know him

A hat on head

I don't know him

A sword in hand

I don't know him.

Although this song is not modifying any negative behaviour directly, anytime the children are reciting it, they will remember the event leading to the death of Patridge and why his children did not die. In many circumstances, children with certain negative behaviours are compelled to drop it because whenever their colleagues are reciting the rhyme or singing the song deals with that behaviour, they do not feel comfortable. The singing of such songs puts peer and societal pressure on the child to drop the unaccepted behaviour.

Another teaching strategy the teacher can use to involve children in their behaviour modification process is by discussions. Substantive issues from the story may be discussed with the children under the leadership of the teacher. Simple questions are asked by the teacher and pupils are allowed to answer them. Some of these questions may be tailored towards the behaviour of a child the teacher intends to modify. Children should also be allowed to brainstorm and come out with feelings concerning certain character's behaviours they heard in the story. It may be done through group discussions, think pair and share model or even through debates. It can also take the form of a miniature panel discussion. Learners should also be allowed to ask questions for clarifictions from their teacher as well as from their peers. These are some of the questions a teacher may use from the third story in her classroom. 
Journal of Education and Practice

ISSN 2520-467X (Online)

Vol.5, Issue No.4, pp $1-22,2021$

www.carijournals.org

Teacher: What is the name of Yiyi's friend?

Children: Đetsyøevi

Teacher: Where was the corn milling machine found?

Children: Forest

Teacher: Who went to carry the corn milling machine onto yiyi's head?

Children: Abuke

Teacher: who is Abuke?

Children: Yiyi’s first son

Teacher: Why did Yiyi become flat?

Children: Because the stone was too heavy. Because the stone does not belong to him. Because he was too greedy.

Teacher: If you were Yiyi, what would you have done?

Children: I will suggest to my friend that we carry the stone to the house so that it gets closer to us. I will be going to collect the corn flour together with my friend. I will not go to the forest to carry the stone. I will be afraid. (suggested responses)

Responses to these questions would generate discussions between the teacher and the children on one hand and among the children on the other hand. Having known the strategy she is using, the teacher may lead the discussions towards a particular deviant behaviour she identified in a child to modify.

VIII.iv Monitoring and support: Children are vulnerable and need the assitance of adults as they learn, especially during the behaviour modification process. The teacher as a 'behaviour technician' has to monitor the negative behaviour undergoing treatment to be sure of the progress being made. She may be able to make out new cases that need reinforcement or to be withdrawn. Random visits to the home of pupils undergoing the behaviour modification treatment is very important for positive results. As said earlier, Ewes train their young ones informally to acquire the profession of their parents to enable them become gainfully employed as they grow. The first story reveals that Partridge was in a farm with her chidren harvesting beans. For instance if a child refuses to go to the farm with the parent before this story was narrated and the teacher uses the necessary measures to modify that behaviour, she may visit the child's home especially during holidays as a follow up to monitor the development. If the visit sees improvement, it must be repeated with verbal rewards such as 'well done, good boy, keep it up' to encourage the child to continue. Such vivits would build a strong collaboration between the school and home in modifying the behaviour of the learner. Alternative should be identified for the child in an urban area where parents do works that do not require child accompaniment. This would serve as a moral 
Journal of Education and Practice

ISSN 2520-467X (Online)

Vol.5, Issue No.4, pp $1-22,2021$

$\underline{\text { www.carijournals.org }}$

booster to help modify the child's behaviour. On the other hand, if the teacher descovers during the visit that there is no change, she has to encourage the child to do the right thing by reminding him of the events in a story and let him know that she would come back. The visit of the teacher is a signal to the child that the teacher cares and loves him. It also demonstrates the position of the school as an agent in support of the family in child development. Since children see their teacher's visit as a social contract, they reciprocate by doing what she tells them during the visit as part of their fulfilment of the contract. The roles of parents are also important as far as monitoring and supporting the child to acquire a desired behaviour is concerned. They are to provide the teacher with the progress reports of their wards regularly to enable the teacher to make informed decisions on how the individul children are responding to the various behaviour treatments and to provide the needed support and feedback.

\section{IVX Conclusion and Recommendation}

Traditional Ewe folktales are clear and explanatory as far as education is concerned. The narrator has a purpose of telling a particular story by directing it at a suspected behaviour, either to enforce it or to shape it to enable the young ones fit into the society in which they found themselves.

In line with Rogoff (2003) argument that individuals develop as participants in their cultural communities, engaging with others in shared endeavors and building on cultural practices of the prior generation, it has been revealed that Traditional Ewe folktales are used as a means of transferring sociocultural values of the people from generation to generation.

Identification of the children's problem behaviours, motivating children to stay in school for behaviour modification process, monitoring and supports are necessary for correcting the children's negative behaviour with the collaborative responsibility of the early grade teacher (the school) and the parents (the home).

Ewes believe that punishing people is a sole responsibility of the gods. Hence they rarely use punishment as a means of correcting people. Rather, they resort to storytelling and rely on it as a measure of moral control and use it as a tool to modify the behaviour of children. From the organization to the end, Ewe folktale narration sessions are governed and regulated by rules, principles and regulations.

Having seen the important roles Traditional Ewe folktales play in the sociocultural development of the child, the following recommendations have been suggested.

- Since it has been established that Traditional Ewe Folktales (storytelling) is duly captured as the 4th sub-strand of the first strand Oral language development (NaCCA, 2019). It will be educationally prudent if in the facilitation of the curriculum the teacher is trained to use it purposely as teaching strategy. This will enable them to tap lessons from Traditional Ewe Folktale to modify children's behaviour in line with the culture of the people. This is necessary because curriculum of the school regardless of its pattern of 
Journal of Education and Practice

ISSN 2520-467X (Online)

Vol.5, Issue No.4, pp $1-22,2021$

$\underline{\text { www.carijournals.org }}$

organization is a selection from the culture of what must be handed over to the new generation (Hama, 2003).

- The ECE teacher must create a safe, encouraging learning environment for effective lesson delivery especially during storrytelling sessions. This supports the claim that early grade is a transition from home to school, the teacher must be warm, friendly, fair, offers praise, encouragement and withhold any form of punishment and threatening behaviours (T-TEL, 2016)

- It is important to employ instructional strategies appropriate for early grade and multi age classes to teach lessons from Traditional Ewe folktales (stories) as an interventional measure to control an identified problem behaviour. In order to cater for all categories of learners in a class, instructional strategies are differentiated and directed at target behaviours learning in one classroom by organizing the classroom to support learning abilities and cater for individual differences (T-TEL, 2016).

- Parents and care givers must be encouraged to collaborate with teachers to use the indigenous knowledge imbedded in Traditional Ewe folktales to modify the behaviour of children by assisting the early grade teachers to develop and teach the pupils short plays from the stories. The children are from the community and are conversant with the community members. This falls in line with an earlier suggestion that teaching and learning would be enhanced if the community members volunteer to support teachers as resource persons in the use of play in the instructional activities of the classroom (Yekple, Vinyo \& Kumah, 2021).

\section{Limitation and further research}

This paper has not been able to fairly integrate the perception and professional competences of the classroom teachers in the use of storytelling. The use of ethnography prevented the researchers to do a composite generalization. A further study in these areas including home-school collaboration, in the use of storytelling as a teaching strategy and other forms of TEF (riddle, puzzle, songs, drum language) is encouraged.

\section{References}

Abadzivor, P. (2014). Literature: Oral and Written. Accra: Ack Publication Limited.

Agyekum, K. (2013). Introduction to Literature. Accra: Adwinsa Publications (Gh) Ltd.

Ali, I. M. (2016). The Impact of Storytelling on Young Ages. European Journal of Language and Literature Studies, 115-119.

Amlor, M. Q. (2016). Imparting IndegenousKnowledge through Traditional Form of Entertainment: The Role of Ewe Play Games. World Journal of Social Sciemces, 1-13. 
Journal of Education and Practice

ISSN 2520-467X (Online)

Vol.5, Issue No.4, pp $1-22,2021$

$\underline{\text { www.carijournals.org }}$

Apprianti, M., Sahrani, R. \& Basaria, D. (2017). The application of Social Story with Positive Reinforcement to Improve Kindergaten Student's Social Skills. Specialty Journal of Psychology and Management, 1-6.

Bandura, A. (1968). Principle of Behavioural Modification. New York: Holt, Reinhart \& Winston.

Bidi-Setsoafia, H. (1989). Togbui Kpeglo II. Accra: Bureau of Ghana Languages.

Ennin, D. (2015). Cybercrime in Ghana A Study of Offenders, Victims and the Law. Accra: University of Ghana.

Erickson, E. (2018). Effects of storrytelling on emotional Development. Minesota: St Cathrine University.

Ferinden, W. (1970). Classroom Management through the Application of Behavior Modification Techniques. Linden: Remediation Associate Inc.

Finnegan, R. (1970). Oral Literature in Africa. Oxford: Oxford University Press.

Fisher, W. (1987). Human communication as narration: Towards a philosophy of reason, value and action. Colombia: University of South Carolina Press.

Gorden, J.B and Kuehner, K. (1999). Fiction: An Introduction to Short Story . Illinois : NTC/ Contemporary, Publishing Group, Inc.

Hama, J. (2003). The school curriculum, a tool for education and national development. Accra: Step Publishers.

Ireland, K. (2021, August 06). Behavioue modification inchildren with temper tantrums. Retrieved from http//docshare01.docshare.tips

Isaac, J. (2010). Methods and strategies of teaching: An overview. Kalapet: Pondicherry University Press.

Kumassah, A. (2016). The most authentic migration saga of the Anlo Ewes. Keta: Photo City Press.

Lawrence, R. L.\& Paige, D. S. (2016). What Our Ancestors Knew: Teaching and Learning through Storytelling.

Micheal, F. Shaughnessy \& Kinsey Kleyn. (n d). The Importance of Childhood Education. New Mexico: Eastern New Mexico University.

Naame, A. P. (2021, April 12). AFRICA/GHANA- "Ritual killings are a treat to National Security" denounce the Bishops. Retrieved from angezia fides: fides.org 
Journal of Education and Practice

ISSN 2520-467X (Online)

Vol.5, Issue No.4, pp $1-22,2021$

$\underline{\text { www.carijournals.org }}$

NaCCA. (2019). Ghanaian language curriculum for primary schools (KG1 - Basic 3). Accra: MoE/GES.

Nyarko-Yerenkyi, A. (2021, May Wednesday). Ghana: 4 Suspected Armed Robbers Killed in Shootout With Police. Ghanaian Times (Accra).

Osman Joshua \& Owhovoriole Felicia. ((nd)). Folktale as a catalist for Moral Instruction in Selected Nigerian Movies. Lagos: Unpublished.

Rose, E. D. (2017). Ewe (Ghana) Storytelling Songs and International Undergraduate Curricullum. Illinois: University of Illinois.

Shabib, N., Naderi, F. \& Makvandi, B. (2015). The effect of Storytelling on Behavioral Problems os preschoolers' in Ahvaz. Journal of Applied Environmental and Biological Science, 353-357.

Skinner, B. F. (1938). The behavior of organisms an experimental analysis. New York: Appleton-Century-Crotis.

T-TEL. (2016). National teachers standard for Ghana: Guidelines. Accra: National Teaching Council.

UNICEP. (2012). Asia pacific end of decade note on Education For All (EFA). Bangkok: UNESCO.

Wanjohi, A. M. (2010). Child Development Theories. Nairobi: KENPRO Publications.

Williams, L. (1975). The American woman:Her changing social, economic and political role, 1920-1970. Journal of Social History, 154-155.

Yekple, S.L.K, Vinyo, I.Y \& Kumah, M.S. (2021). Developing Literacy And Numeracy In Early Childhood Education In Ghana: The Role Of Traditional Ewe Play Games. International Journal of Progressive Sciences and Technologies (IJPSAT), 215-226.

Yendaw, E. \& Dayour, F. (2015). Effects of the national school feeding program on pupils enrolment, and retention. A case study of Nyoglo of Savelugu Nantong Municipality, Ghana. ResearchGate, 340-353. 